\title{
Do you even know what public archaeology is? Trends, theory, practice, ethics
}

\author{
Lorna-Jane Richardson and Jaime Almansa-Sánchez
}

\begin{abstract}
Archaeology is a discipline influenced by emerging cultural trends, especially with regard to theoretical approaches to interpretation and practice. Public archaeology is a relatively young approach, still finding its feet, and loose definitions of it have opened the door to multiple perspectives and opportunities. When research agendas include the issue of public engagement, we need to approach our practices critically from the beginning, and consider the consequences of 'doing' public archaeology. Moving beyond an understanding of the theoretical backdrop to our work, we first need to situate our work socially, politically and economically. This article will bring necessary critique to some current trends in public archaeology, proposing that commitment to sustainability, inclusivity and ethics are the basis for a responsible practice.
\end{abstract}

\section{Keywords}

Public archaeology; ethics; theory; practice; politics; economy.

Trends in public archaeology

Public archaeology can be defined as both a disciplinary practice and a theoretical position, which can be exercised through the democratization of archaeological communication, activity or administration, through communication with the public, involvement of the public or the preservation and administration of archaeological resources for public benefit by voluntary or statutory organizations. Broadly understood as a sub-discipline, public archaeology is as much

Lorna-Jane Richardson and Jaime Almansa-Sánchez are current co-chairs of the Working Group in Public Archaeology at the European Association of Archaeology. 

an activity as a theoretical concept, and operates in a wide variety of societal, social and academic contexts (Schadla-Hall, Moshenska and Thornton 2010; Matsuda and Okamura

2011; Skeates, McDavid and Carman 2012), which makes it more than a new label for archaeology. Its application has been practical in a wide variety of disparate contexts: the intersection of archaeology, politics and policy (Ucko 1995, 1997); cultural heritage management and museums (Merriman and Swain 1999; Merriman 2000); indigenous rights and nationalism (Fawcett, Habu and Matsunaga 2008; Rassool 2010); reconstruction and re-enactment (Anderson 1985; Benson, Brier and Rosenzweig 1986); the representation of the past in interpretation (Jameson 1997; Merriman 2002); the historiography of archaeology (Hudson

1981; Jones 1984); heritage tourism (Robinson and Picard 2006); heritage education and curriculum design (Corbishley 2011); public engagement and outreach (Moser et al. 2002; Jensen 2010); archaeological ethics and the law (Faulkner 2000; Schadla-Hall 2004); archaeological journalism and archaeology in the media (Piccini 2006, 2010); archaeology in popular culture (Holtorf 2005a, 2005b, 2006, 2007); and 'heritage' - tangible and intangible (Waterton and Smith 2010; Waterton 2010). This wide remit for the subject can lead to confusion; the description of what exactly a public archaeologist actually does, and whether the public archaeologist is concerned with theory, research or practice continues to be the subject of ongoing debate (Matsuda and Okamura 2011; The Public Archaeology Group 2013). The professional experiences and research interests of the authors of this article led to the establishment of the European Association of Archaeologists Public Archaeology Working Group in 2013. This Working Group aims to create a network of professionals involved with public archaeology that cross-cuts the silos of individual archaeological organizations, helps facilitate the definition of 'public archaeology' and the exchange of examples of best practice from our experiences. Writing from the viewpoint of the Working Group, this article will further extend the debate around the definition and application of public archaeology from a global perspective.

Many of the key issues for debate in public archaeology are not new. Six decades ago, Sir Mortimer Wheeler wrote that archaeologists are obliged to disseminate their fondhegs

public: 'It is the duty of the archaeologist, as of the scientist, to reach and impress the public, and to mould his words in the common clay of its forthright understanding' (Wheeler 1956, 234). Despite this awareness, the mid-twentieth century saw the development of an academic discourse that was, at times, obscure and elitist, and had rendered archaeology inaccessible to the general public. According to Hawkes:

Some discussions of archaeology have seemed to me so esoteric, so overburdened with unhelpful jargon, so grossly inflated in relation to the significance of the matters involved, that they might emanate from a secret society, an introverted group of specialists enjoying their often rather squalid intellectual spells and ritual at the expense of an outside world to which they will contribute nothing that is enjoyable, generally interesting or of historical importance.

(Hawkes 1968, 256)

This was later echoed by the American archaeologists Fritz and Plog, who wrote that 'unless archaeologists find ways to make their research increasingly relevant to the modern world, the modern world will find itself increasingly capable of getting along without archaeologists' (1970, 412). 
The tradition of post-processual archaeological theory grew in popularity within academic archaeology during the late 1970s and early 1980s, and drew inspiration from the social sciences, Marxism, interpretative anthropology, structuralism, post-structuralism, gender studies and critical theory, to propose that there was no single paradigm of archaeological interpretation (Ucko 1995; Johnson 1999). Post-processualism as a theoretical concept emphasizes the subjectivity of archaeological interpretations, the importance of locating material culture contextually within archaeological interpretation, the importance of personal agency and the fact that the act of interpretation of the past possesses political resonance in the present. Influenced by these post-processual attitudes towards archaeological interpretation, the subsequent decades have seen the topic of communication between archaeology as a discipline and the wider public move beyond a 'technical exercise of dissemination' (Merriman 2002, 541) to become a subject that is an accepted part of academic study within archaeology.

There are many diverse meanings and contexts for public archaeology in the academic literature. The term 'public archaeology' has been in use since the publication of McGimsey's book Public Archeology in the USA - as a term used within the context of publicly funded and supported excavation and preservation of archaeological sites threatened by development works (McGimsey 1972). In the USA, this term is still applied within a discipline heavily focused on public-benefit cultural resource management (CRM) (McManamon 2000; McDavid and McGhee 2010; Matsuda and Okamura 2011). The foundation of the World Archaeological Congress in 1986 took a different approach, with an early manifestation of a socially responsible, reflexive and self-aware archaeology, established to:

promote: the exchange of results from archaeological research; professional training and public education for disadvantaged nations, groups and communities; the empowerment and support of Indigenous groups and First Nations peoples; and the conservation of archaeological sites.

(World Archaeological Congress 2013)

Much of the European-focused literature on the subject defines public archaeology as an examination of the relationship between archaeology and the public, where the public of public archaeology is represented both by the state, working in the public interest to protect, excavate and investigate society's archaeology on their behalf, and by the notional 'general public', defined as those who are not professional archaeologists (Schadla-Hall 1999; Ascherson 2000; Merriman 2004).

A wider and deeper view of the worldwide contexts in which public archaeology is undertaken globally is beyond the scope of this article, but we believe it is important to at least offer some notes on the situation of the subject outside the better-known contexts of Europe and its parallels in the USA. However, there are two essential issues to consider; first, the steady growth of interest in conducting public archaeology; second, the patently peripheral position of public archaeology practices outside the sphere of Anglo-Saxon influence.

In South America, we can see a struggle between a public archaeology focusing on education and community work (Endere 2007; Saucedo Segami 2011; Funari and Bezerra 2012; Lizama Aranda and Camargo Bod(Gill 2014) and a radical opposition to cultural resource management, understood as a liberal practice that endangers research (Gnecco and Dias, forthcoming). 
The development of Latin-American Social Archaeology from the 1970s (Tantaleán and Aguilar 2012) has set an agenda of postcolonial practice and community engagement that opened a new theoretical and practical arena, very close and parallel to the process in Europe and the USA.

Africa is experiencing a similar situation, with a great heterogeneity in the way public archaeology is understood, either from a CRM perspective (Naffé, Lanfranchi and Schlanger 2008), or a community approach (Eze-Uzomaka 2000; Almansa et al. 2011), or a critical postcolonial one (Shepherd 2011; Thiaw 2011). As many of the professionals working in the continent are still drawn from foreign countries, there are, inevitably, differing approaches to the development and application of management strategies and research. This will undoubtedly change with a growth in the number of home-grown professional archaeologists.

Something similar is happening in Asia, where the differences in the national approaches to archaeology are important, and the lack of professionalization in most of them makes it difficult to find any common approaches (Okamura 2011; Shoocongdej 2011; Wang 2011; Chakrabati 2012; Corbishley and Jorayev 2014; Garazhian 2014). The reference list offered with this article demonstrates some of the examples of public archaeology projects currently taking place in these different countries.

The landscape of public archaeology in Oceania has been poorly studied beyond Australia, which can be included in the Anglo-Saxon sphere, and is the model for the area (Byrne 2004; Sand, Bolé and Ouetcho 2011).

Theory and public archaeology

Returning to the UK, Belford has written that the historic environment is a 'contested' landscape, with an academically dominated interpretative ideology, which presents the past to the non-specialist public, supported by the ownership of requisite expert authority $(2011,50)$. The authoritative definition of what constitutes archaeology is placed in the hands of the educated, trained and experienced archaeologist. This real, or perceived, concept of archaeological authority has been further legitimized by the development of a professionally skilled and educated workforce in many countries, and by national and international legislation protecting archaeological monuments and material. This section will discuss the various models of public archaeology presented by archaeologists working in the sub-discipline, which are drawn from discussions on the epistemological understandings of the communication of scientific knowledge (Matsuda and Okamura 2011, 6), illustrated in Table 1. Differing theoretical approaches to archaeology can be found in different countries, depending on the history of the foundation of the national disciplinary tradition. These approaches have developed alongside the socioeconomic and political circumstances under which publicly accessible and publicly understandable archaeology takes place, and is subject to policy, which varies from nation to nation (McGuire 2008; Matsuda and Okamura 2011).

Merriman (2004) offers two models for public archaeology: first, the 'deficit model', which is derived from the discipline of science communications and emphasizes the importance of experts encouraging a better public understanding of science, for both its economic value and its benefits for citizenship (Irwin and Wynne 1996; Macdonald 2002). Merriman locates the application of this scientifion ddfic $\quad$ in the area of public archaeology practice where the archaeological discipline attempts to promote the need for professional, expert archaeologists to 
Table 1 Approaches to archaeology suggested by Merriman, Holtorf, and Matsuda and Okamura (Matsuda and Okamura 2011,6)

\begin{tabular}{|c|c|c|c|}
\hline \multirow[b]{2}{*}{$\begin{array}{l}\text { Four approaches } \\
\text { archaeology }\end{array}$} & \multicolumn{2}{|c|}{ More practice-oriented } & More theory-oriented \\
\hline & $\begin{array}{l}\text { Educational } \\
\text { approach }\end{array}$ & $\begin{array}{l}\text { Public relations } \\
\text { approach }\end{array}$ & $\begin{array}{ll} & \text { Multivocal } \\
\text { Critical approach } & \text { approach }\end{array}$ \\
\hline $\begin{array}{l}\text { Corresponding models suggested } \\
\text { by Merriman (2004) }\end{array}$ & Deficit model & & Multiple perspective model \\
\hline $\begin{array}{l}\text { Corresponding models suggested } \\
\text { by Holtorf }(2007)\end{array}$ & $\begin{array}{l}\text { Education } \\
\text { model }\end{array}$ & $\begin{array}{l}\text { Public relations } \\
\text { model }\end{array}$ & Democratic model \\
\hline
\end{tabular}

educate the (amorphous) public on how to appreciate archaeology 'correctly' (Merriman 2004, 6). Merriman notes the flaws in this 'deficit model' for public archaeology, and offers an alternative 'multiple perspectives model', in the light of challenges to the deficit approach in science communications (Holliman, Thomas, et al. 2009; Holliman, Whitelegg, et al. 2009). This model is especially important, since it acknowledges the importance of agency in public encounters with archaeological data and archaeological sites, as well as the need for an understanding of certain core public values regarding archaeology (Merriman 2004). The multiple perspectives model suggests that archaeologists should engage with the public on archaeological issues from a desire to enrich people's lives and stimulate thought, emotion and creativity, although Merriman urges caution around what Schadla-Hall terms 'alternative' public archaeologies in a Western context (Merriman 2004, 7; Schadla-Hall 2004, 255). The tension between multi-vocality and disciplinary authority is not only a matter of elitist hierarchy and postmodernist hyper-relativism (Evans 1997, 205). An acceptance of multi-vocal responses to archaeological evidence also offers opportunities for the misuse of archaeological evidence in the service of political, ethnic, religious or nationalist agendas.

Holtorf (2007) offers three models for the practice of public archaeology: the 'education model', the 'public relations model' and the 'democratic model'. The 'education model' suggests that archaeologists need to support the public to 'come to see both the past and the occupation of the archaeologist in the same terms as the professional archaeologists themselves' (Holtorf 2007, 109). The 'public relations model' suggests that an increase in social, economic and political support for the professional archaeological sector will arrive only if archaeologists can improve their public image (Holtorf 2007, 119). As a contrast to these models, which see the public as passive recipients of professional archaeological advice, education or lobbying, the 'democratic model' proposes that everyone, regardless of education, profession or training. be supported to 'develop their own enthusiasm and "grassroots" interest in archaeology' (Holtorf 2007, 119).

Moshenska defines public archaeology as part of the discipline of archaeology that studies and critiques the political, social, cultural and ethical areas of archaeology, as well as 'the processes of production and consumption of archaeological commodities' $(2010,47)$. If the remit and value of public archaeology are to provide a method of understanding the public demand for Moshenska's archaeological 'commodities' - be these archaeological artefacts and sites, archaeological experiences or archaeological knowledge - then public archaeology has to provide data for the archaeological 'industry' on public consumption of archaeological informa- tion (Burtenshaw 2010, 49). However, as Grima emphasizes, we cannot ignore the impact of 
archaeological ethics, power relationships and co-creation and reduce the paradigm of public archaeology to one that simply returns to a deficit model of archaeological knowledge (Grima 2004, 2010).

Matsuda and Okamura $(2011,6)$ propose four different theoretical approaches to public archaeology, reflecting the work of Merriman and Holtorf: 'educational', 'public relations', 'critical' and 'multi-vocal'. The 'educational' approach lends the expert voice to the communication of archaeological information to non-archaeologists. This 'public relations' approach is that formulated by Holtorf (2007). Matsuda and Okamura's work extends these models by distinguishing between the 'critical and multi-vocal approached in Merriman's multiperspective and Holtorf's democratic model' with a nuance added from an application of 'critical and hermeneutic epistemologies in archaeological theory' $(2011,5)$. Matsuda and Okamura's 'cri- tical' $(2011,5)$ approach focuses on the examination of socio-political power relationships in the negotiation, implementation and management of interpretations of archaeological material and practice (Shanks and Tilley 1987; Ucko 1990; Hodder 2002). It examines the subjectivity involved in these differing interactions and power relations between material culture, groups and individuals that are both historically situated and in the present. This critical approach firmly emphasizes the importance of broader dialogue between the socioeconomically and politically marginalized and archaeological knowledge and resources, as part of the achievement of wider cultural meaning. (Faulkner 2000; McDavid 2004).

Matsuda and Okamura's 'multi-vocal' approach to public archaeology acknowledges the diversity of and differences in the interactions between humans and the material culture of the past 'based on a hermeneutic epistemology' (60.1Their interpretation of the concept of a

multi-vocal approach to archaeology seeks to recognize, understand and acknowledge the broad view of the "various interpretations of archaeological materials made by different social groups and individuals in various contexts of contemporary society' $(2011,6)$. This is in nuanced contrast to their understanding of the critical approach 'which is to highlight a specific meaning of the past, sometimes to socially privileged groups to counter their socio-political domination (Faulkner 2000), and at other times to socially marginalized groups to help them achieve due socio-political recognition (Bender 1998; McDavid 2004)' (Matsuda and Okamura 2011, 6).

All these models for public involvement with archaeology are intended to have a profound and transformative impact on the discipline, and the social practice of communication and representation (Giaccardi 2012), which we can understand as the formal representation of knowledge, the representation of the interests and ideas of communities and participants, as well the representation of the practice of archaeological expertise. These models support access by non-experts to archaeological resources and data - some without including the direction and leadership of professional archaeologists.

Public archaeology in practice

In each of the national arenas mentioned above, 'audiences', 'communities' and 'management' are common terms for every approach to public archaeology, however it is understood or applied. Central to an understanding of public archaeology as practice must be an understanding of its audiences and an understanding of what archaeology is or what it does, and what it is for. Archaeologists need to consider who their audiences and communities are, using a range of 
scales. They need to attempt to understand whether these different audiences are receptive to their archaeological information and discussion and whether they, as professionals, can understand the requirements of these diverse groups, to enable the professionals to support and encourage connections with archaeological heritage (Angelo 2013).

In the academic literature, the greatest entanglements of concepts and theories of public archaeology are around issues of definition, application and conflation of the terms 'public' and 'community'. Who are the 'publics' of public archaeology? Are these audiences for the production and consumption of archaeological information simply local communities? Do these audiences also include tourist organizations, religious groups, construction companies, housing developers, media outlets, newspapers, consumers of historical television programmes, dealers in antiquities, nationalists and politicians? It is essential to acknowledge the impossibility of considering a general, single and homogeneous public archaeology, especially when the concept of 'public' and 'archaeology' are socially, culturally and geographically situated.

This is why practice is as important for public archaeology, either as the location of research or fieldwork with communities. However interesting our theory, action is essential for the advance of public archaeology and the reaching of our goals as professionals. Within these actions, communities play an essential role in which an ethical approach is of vital importance.

As Crooke $(2010,19)$ notes, membership of a local, situated community is an interaction that takes place within a self-defined identity framework and involves some form of community hierarchy. Organizational membership has multi-layered motivations. These can be based on established interests, personal affinity with geographical location or local ancestry and the acting out of cultural identity and interests (Isherwood 2009). Membership of a community based on geographical location, for example, has to be renegotiated in an era of greater urbanization,

population mobility and transience, alongside demographic, linguistic and socio-economic differences (Isherwood 2009; Crooke 2010). Community groups may have distinct expectations of the demographic of their membership, especially in areas with contested or controversial community identities (Crooke 2010). For those of us working within the archaeology sector, especially in the UK and North America, it is important not to forget that, for many community volunteers and avocational enthusiasts, archaeology and heritage is a recreational leisure pursuit. It is an important cultural and social activity, but recreational nevertheless. As Waterton (2005, 315 ) has observed, the attempt by professionals to encourage community cohesion or a 'sense of place' through cultural heritage often ignores existing community relationships and interactions between residents and their local heritage landscape, which may not be manifest when judged against an archaeological expert's scale.

The extent to which expert-led methodologies and interpretations of archaeological practice within 'community' settings can support broad, counter-hierarchical participation and the degree to which these methodologies and interpretations support diverse perspectives must be ques- tioned against the backdrop of the available demographic statistics regarding membership of both professional and voluntary sector organizations.

The UK has a strong tradition of undertaking research and practice that examines and supports the relationship between archaeology and contemporary society and as such has a significant body of data with which to analyse these issues. According to research undertaken in 2013 on behalf of the Institute for Archaeologists (Aitchison and Macqueen 2013), the demographic profile of professional archaeologists is predominantly white (99 per cent) which contrasts with the entire UK workforce of whom 13 per cent were of black, Asian or minority 
ethnic origins. This research also shows that 54 per cent of the archaeological workforce is male; one in five professional archaeologists are in possession of a $\mathrm{PhD}, 47$ per cent hold a Master's level qualification and 93 per cent hold a Bachelor's degree or higher. The Council for British Archaeology Community Archaeology Report (Thomas, 2010) appears to indicate that the average age of a voluntary-sector archaeological society member in the UK is around 55 , while a history society member is typically over 60 years old. Further work to unpick the demography of participation in public archaeology in other countries would be enlightening.

How far then do the interests of local communities reflect that of the wider public as a whole? Can community archaeology become a 'living narrative involving local people' (Reid 2008, 21) or has community archaeology been rebranded and re-professionalized and steered back into the control of trained and paid archaeologists? The variety of archaeological and historical pasts that are chosen by community archaeology groups and projects for exploration are selected from a number of available 'pasts', and many other histories will not be examined (Ashworth 1994). Specific heritage communities may have been selected to authorize the redevelopment of urban and rural landscapes or to reinforce fragile community identities in the light of dispersed populations (Belford 2011). Underlying the application of the term 'community archaeology' to a group or project is an assumption that 'community' can be described as a defined and homogeneous static entity, with members that share common experiences and values. However, social relationships are rarely straightforward, and the 'rhetoric of community' (Waterton and Smith 2010, 8), especially at policy level, glosses over nuanced interactions and relationships between an individual with an interest in archaeology and the functions of civic and volunteer- led society at local, regional and national levels.

Questioning the dominant position of the heritage professional can be an uncomfortable business for those working in the profession. It should be highlighted that those who comment on the practice, meaning and outcomes of community archaeology are rarely active members of those communities themselves. According to Holtorf and Högberg $(2005,80)$ there are two essential areas of knowledge that community archaeology requires its practitioners to acquire: an understanding of archaeological resources, including the creation of archaeological interpretations based on scientifically obtained archaeological evidence. and an understanding of contemporary society and its interaction with the past. Any negotiation between archaeological professional and community volunteer around issues of expert knowledge and the ownership and control of community-led or community-focused projects is meaningless unless these communities are actively engaged with the process of managing the projects, rather than simply being involved as passive recipients of outreach work or receiving an explanation of the work undertaken by the professionals as an end product (Waterton 2005; Emerick 2009).

Unpacking some of the assumptions that professional archaeologists make about the meaning of participation is essential, and raises the question of whether we need a conclusive definition of community archaeology at all - if it is more of a process than a method. What kind of engagement with the past do we, as archaeological experts, expect the public to have? Are we offering nothing more than a balm to a 'passive, grateful audience' (Rassool 2010, 81)? Do we expect them to engage with the past through a theoretical lens of our expert scientific deduction or is an emotional response to an archaeological past that has personal meaning acceptable to us, as it is to the 'uneducated' public (Henson 2010, 2)?

Organizations undertaking work under the banner of community archaeology are disparate, often grant-funded and therefore short-term and bring their own sub-disciplinary theories, 
traditions and practice to the community table. Academic models and approaches to the issue of practice, or how to manage community archaeology projects, tend to adopt one of two methodological orientations. Marshall (2002), Moser et al. (2002) and Tully (2007) see community archaeology as a carefully managed collaboration led by professional archaeological experts, with amateur participants. Tully (2007) defined the practice of this approach as public participation in archaeological work with the aim, methods and work overseen and controlled by the expert archaeologists. In this setting, when professionals undertake archaeological work within the context of a community archaeology project context, for example during an excavation supported by voluntary, amateur assistance, the professional archaeological expert is ultimately responsible for the identification of the archaeological contexts and artefacts, overseeing data collection, processing these data and formulating the final interpretations. Belford $(2011,64)$ argues that the 'top-down' approach to community archaeology maintains the expert status of the professional archaeologist, who gives voice to the opinions and interpretations of the community participants only when the archaeological experts validate these.

While this approach to community involvement in archaeological work promotes an element of carefully controlled non-professional participation, simply allowing non-professional parties to be involved in something labelled a 'community archaeology' project does not mean that its practice is truly participatory and inclusive. Belford (2011) makes a strong case that this approach excludes only those individuals and community groups that choose to be excluded from the projects and process. In the UK prevailing political agendas have aimed to use cultural heritage as an instrument for social policy - to combat social exclusion, support social cohesion, create a 'Big Society' and support equality of access to heritage sites and information. Within this UK context, this support has inevitably driven resources and funding for community archaeology projects along this 'top-down' model. This has often taken place out of financial and administrative necessity, and is complicit with political policy for any institution or organization in receipt of public money, and this brings with it a relatively passive role for the non-expert public.

The commodification of archaeological practice is probably the trigger for most of the pitfalls we encounter in daily management (Almansa 2015). There is increasingly brutal competition for funding, especially in the aftermath of a global economic crisis, and archaeology is no stranger to that problem (see Schlanger and Aitchison 2010).

While research agendas are set, the goals of traditional projects adapt to new situations, not in practice, but on paper, using concepts of public engagement and participation that might lead to the approval of those projects and their funding. Our question here is: do these projects really understand what they are applying to do? Public archaeology is not only a matter of working with communities or providing educational opportunities. It is about management and the construction of knowledge and the concept of heritage. Sharing your findings with the public is not 'public archaeology' by itself, and we hope this article provides some clarity.

The idea of involving communities in archaeological practice is an attractive proposition, and already part of our work in many countries. In the UK there has been a long tradition of public involvement (Moshenska and Schadla-Hall 2011), but in others, like Spain, it was misunderstood or insufficient (Almansa 2013), in spite of its claim to a long tradition (Moreno Torres and Marquez-Grant 2011). The discourse around public archaeology after its explosion in the early 2000s was an obvious critique of the way we interacted with the present, so obvious in fact, that institutions adopted it as a boost to their outreach activities. Unfortunately we lack a study of 
this fact, but we can find a parallel in the use of the word 'heritage' in the titles of the new history and archaeology courses in Spain (Querol 2011).

The main problem was that these practises sprung from an untested hypothesis. Who was going to those sites? Why? In some cases, there was no real planning or sustainability in these outreach initiatives and quest for impact. There was no target, no discourse and no tangible aim besides the tick-box success of quantity of audience (Almansa 2011; Hughes 2011). There was no public archaeology, just poorly understood community engagement. Ironically, the concept died of success.

Public archaeology and ethics

Matsuda and Okamura wrote that the choice of approach to public archaeology is a political act and results in 'a distinctive form of public archaeology in each context' $(2011,6)$. One of the central ethical paradigms for public archaeology includes the examination of socio-political relationships between archaeology and contemporary society, and the renegotiation of power and control through participation, communication and dialogue between archaeological professionals and non-professional members of the general public.

However, as Evans argues, while these post-modernist (and post-processual) approaches to the past should compel us to rethink the 'categories and assumptions' within which we work, 'we really can, if we are very scrupulous and careful and self-critical, find out how it [history] happened and reach some tenable though always less than final conclusions about what it all meant' (Evans 1997, 252-3). As a discipline, archaeology has to be politically engaged in order to explore the policies to which it is subject, to understand the history, foundation and application of associated academic theory and to explore and analyse public archaeology in practice. Since archaeology is a subject that is in a constant state of dialogue with itself, and with the past, the relationship between the present and past is situated, complex and subjective applicable from the perspective equally of professional archaeologist or non-professional member of the public. One of the roles of public archaeology is to critique the process and means through which the archaeological sector influences, facilitates, limits and exposes these relationships among the past, present and future. However, without robust statistical evidence to gauge the level of public support and interest in archaeology, the discipline becomes vulnerable (Schadla-Hall 1999). In the current era of global economic austerity, with increasing cuts to public funding for archaeological work in Europe and beyond, there is greater need than ever before for research that can examine 'both the economic and cultural values and impacts of archaeological resources' (Schadla-Hall, Moshenska and Thornton 2010, 62).

Ethics have been a long debated topic in the history of philosophy. Today, we still debate it, also in relation to deontological practice. Depending on the trend among deontological theory the right and the good might mean different things and prevail one over the other (Kamm 2007). Both agent-centred and patient-centred deontological theories can be of use, but at the same time they remain contradictory in many terms. As professionals, we might be affected by contractarian deontological theories (Scanlon 2003), where our codes, contracts and laws determine what is right and wrong. However, there are always reasons to question them. On this line, we might question a meta-ethical background that is not 
associated to religion, which makes choices far more difficult and subjective (Moore 2004). How then can we even think to be ethical?

If we go back to the definition of public archaeology outlined above, we find some structural concepts to take into account: society, economy and politics. They represent the bedrock of our scope as public archaeologists. As researchers, the wide range of topics we can approach is almost infinite. Understanding the multiple ways in which people affect and are affected by archaeology does not represent any threat to our ethical approaches and behaviour. One of the roles of public archaeology as part of a theoretically driven discipline is the examination of the relationship among the many interpretations of past human activities and contemporary society, in the light of the gathering, processing and re-examination of old and new archaeological data. Copeland (2004), Hodder (1992, 1999, 2000, 2004, 2008) and Smith (2006) place emphasis on the need for, and ethical responsibility of, archaeologists involved in the presentation of their work in the public realm to understand, respect and value the interpretations of the past by non-professionals, without the imposition of their 'correct' interpretational methods.

In the end, this just means words, although words can trigger actions. We could appeal to social justice or human rights as the limits, but where does the ethical controversy start? Is it unethical to support a cause you firmly believe in? And to pledge against a law you find unfair? Many of us have been in that position at some point, and in these cases both sides of a single coin can be ethical and unethical depending on the point of view, but both, simultaneously, public archaeology.

However, practice has different consequences and the actions that come when we make public archaeology happen, might be detrimental for archaeology, heritage or people.

What happens when we fail to communicate our archaeologies to the public? Whether this is inaction during our fieldwork, conflict with workers or unclear discourses in outreach activities, not doing something is failing as archaeologists, so the lack of public archaeology in a project is an ethical breach itself. Although the codes of practice approved by different associations in some way refer to aspects clearly related to public archaeology as a practice, only the IfA Code (2013) is binding as a by-law (which means there are repercussions for those who do not follow it). Meanwhile, failing to comply with other ethical policies (like those for the WAC, EAA, SAA, etc.), which also contain some interesting notes, has no serious repercussions for those who break these. Everybody feels ready to conduct public archaeology, but it must be planned and designed as are other facets of the archaeological project. In the same way that we contract specialists for chemical/physical analysis, we need specialists to deal with communities. At this point, targeting groups, understanding our audience and preparing adapted materials that can meet our goals for the programme, are essential parts of any project. As stated before, it is not just about bringing visitors to a site. The wrong approach might lead to negative feelings towards archaeology (or archaeologists), incorrect information about our work disseminated to the public or political and social conflict leading to the destruction of archaeological sites and artefacts, looting or social opposition to the preservation of sites and monuments. We must be careful with the message we transmit.

We strongly believe that our role as public archaeologists is to engage people in a positive way, helping them to understand and value our profession and the results of our work. If our work interferes in a way with a community, we need to be extremely careful, as people are more important than dusty ruins. It is our duty to solve conflicts, not to create them, and here we 
return to the issues of archaeological research and its potential impacts on the communities and societies within which it takes place.

Concluding thoughts

The experiences of the founders of the European Association of Archaeologists Public Archaeology Working Group (2013) outlined in this article and an overview of the current situation of public archaeology worldwide (Matsuda and Okamura 2011; Skeates, McDavid and Carman 2012) highlight two important facts. Public archaeology seems to be gaining support and followers exponentially. However, there is still an unclear idea of what public archaeology is and what it means. Despite the broad paradigm of the discipline, most professionals still conceptualize it only in terms of site-based outreach activities or community work. Communities are important for public archaeology, but this needs to be understood from a wider perspective, where archaeology is much more than a weekend hobby and where it affects daily lives in different ways - an argument perhaps beyond the remit of this article.

In order to make public archaeology happen we only need commitment (and a lot of research, and maybe imagination). Nonetheless, having the good will to do things does not mean we are doing them well. Looking at the theory behind public archaeology and the debates around its practice, we can see how controversial and difficult this subject can be, especially since we are still undertaking basic research on it. Although outreach or community involvement might be mandatory in some publicly funded projects, first of all we need the commitment of the collective discipline to assimilate the goals of public archaeology and include them in the design of their projects. We desperately need archaeologists interested in the public, but also professional public archaeologists.

Professionalizing public archaeology means researchers and practitioners fully devoted to the subject and capable of designing effective, quality projects and putting them into practice. We cannot keep considering this our hobby, and the increase of research opportunities and paid positions in public archaeology-related topics is a signal of positive structural change. However, we need to see this professionalization in the context of cross-disciplinary projects, on the same level as other disciplines completely integrated into current archaeological research.

The political and economic facets of public archaeology are still under-researched, and yet the social impact of community archaeology seems to be too successful to be true (we can recall

only one publication showing problems with a community: Mapunda 2013). Are we really always that successful? Or we are afraid of showing (and publishing) our failures? In a subject that has grown up inextricably linked with practice, there must be more examples to learn from.

Our concerns as authors and professionals are that we stand at an ethical crossroads. The unchecked practice of so-called public-archaeology projects due to what we have here identified

as a practice of trend and fashion (with its intrinsic value for obtaining funding) endangers the discipline and risks its ethical practice.

Ethics is essential for public archaeology, as we are not dealing only with material remains, or heritage, but with human beings. The consequences of our actions can be highly negative if we fail to understand and practice a good public archaeology. We are not defining here what a 'good' public archaeology is, but we certainly advise practitioners to be extremely careful and 
think about it as a discipline that needs professional public archaeologists. It may sound contradictory to call for professional public archaeologists while at the same time encouraging non-professionals to practise our mother discipline, but this is exactly why we need to make clear the goals and methods of public archaeology practice.

This article has reviewed what we currently understand as public archaeology and how we try to theorize it, but overall it has tried to highlight the need for a responsible and ethical practice. This practice must place front and centre the commitment of archaeology professionals to a better, sustainable archaeology through public archaeology, one which moves beyond trends and the requirements of funding bodies, in order to consider and accommodate the needs and values of the communities and colleagues with whom we work.

\title{
Disclosure statement
}

No potential conflict of interest was reported by the authors.

\author{
Lorna-Jane Richardson \\ University College London \\ Jaime Almansa-Sánchez \\ JAS Arqueología S.L.U. \\ almansasanchez@gmail.com
}

\section{References}

Aitchison, K., and D. Macqueen. 2013. "Archaeology Labour Market Intelligence: Profiling the Profession 2012-13." Landward Research Accessed January 16, 2014. http://www.landward.eu/2013/10/archaeology- labour-market-intelligence-profiling-the-profession-201213.html

Almansa, J., ed. 2011. El futuro de la arqueología en España. Madrid: JAS Arqueología Editorial.

Almansa, J., ed. 2013. Arqueología Pública en España. Madrid: JAS Arqueología Editorial.

Almansa, J. 2015. "Trading Archaeology Is Not Just a Matter of Antiquities. Archaeological Practice as a Commodity." In Ethics and Archaeological Praxis. Ethical Archaeologies: The Politics of Social Justice 1, edited by C. Gnecco and D. Lippert, 141-58. London: Springer.

Almansa, J., G. Belay, D. Tibebu, V. Fernández, J. De Torres, C. Charro, and C. Cañete. 2011. "The Azazo Project: Archaeology and the Community in Ethiopia." Public Archaeology 10 (3): 159-79. doi:10.1179/ 175355311 X13149692332358.

Anderson, J. 1985. The Living History Source Book. Nashville, TN: AALSH.

Angelo, D. 2013. "The Move Towards Public Archaeology." In Encyclopedia of Global Archaeology, edited by C. Smith. New York: Springer. Accessed March 18, 2014. https://www.academia.edu/4033713/ EGA_entry_The_Move_Towards_Public_Archaeology

Ascherson, N. 2000. "Editorial.” Public Archaeology 1 (1): 1-4. doi:10.1179/pua.2000.1.1.1.

Ashworth, G. J. 1994. "From History to Heritage - from Heritage to Identity: In Search of Concepts and Models." In Building a New Heritage: Tourism, Culture and Identity in the New Europe, edited by G. J. Ashworth and P. J. Larkham. London: Routledge. 
Belford, P. 2011. "Archaeology, Community and Identity in an English New Town." The Historic Environment 2 (1): 49-67. doi:10.1179/175675011X12943261434602.

Bender, B. 1998. Stonehenge: Making Space. Oxford: Berg.

Benson, S. P., S. Brier, and R. Rosenzweig, eds. 1986. Presenting the Past. Philadelphia: Temple University Press.

Burtenshaw, P. 2010. "A Reply to "What is Public Archaeology?"." Present Pasts 1. Accessed March 16, 2014. doi:10.5334/pp.8.

Byrne, D. 2004. "Archaeology in Reverse: The Flow of Aboriginal People and Their Remains through the Space of New South Wales." In Public Archaeology, edited by N. Merriman, 240-54. London: Routledge.

Chakrabati, D. K. 2012. "Archaeology and Politics in the Third World, with Special Reference to India." In The Oxford Handbook of Public Archaeology, edited by R. Skeates, C. McDavid, and J. Carman, 11632. Oxford: Oxford University Press.

Copeland, T. 2004. "Presenting Archaeology to the Public: Constructing Insights On-Site." In Public Archaeology, edited by N. Merriman, 132-44. London: Routledge.

Corbishley, M. 2011. Pinning Down the Past: Archaeology, Heritage, and Education Today. Woodbridge, VA: Boydell Press.

Corbishley, M., and G. Jorayev. 2014. "Politics, Archaeology and Education: Ancient Merv, Turkmenistan." In Public Participation in Archaeology, edited by S. Thomas and J. Lea, 119-28. Woodbridge, VA: Boydell Press.

Crooke, E. 2010. "The Politics of Community Heritage: Motivations, Authority and Control." International Journal of Heritage Studies 16 (1-2): 16-29. doi:10.1080/13527250903441705.

Emerick, K. 2009. "Archaeology and the Cultural Heritage Management 'Toolkit': The Example of a Community Heritage Project at Cawood, North Yorkshire.” In Taking Archaeology Out of Heritage, edited by E. Waterton and L. Smith, 9116. Cambridge: Cambridge Scholars Publishing.

Endere, M. L. 2007. Management of Archaeological Sites and the Public in Argentina. BAR International Series 1708. Oxford: Archaeopress.

Evans, R. J. 1997. In Defence of History. London: Granta Publications.

Eze-Uzomaka, P. I. 2000. Museums, Archaeologists and Indigenous People. Archaeology and the public in Nigeria. BAR International Series 904. Oxford: Archaeopress.

Faulkner, N. 2000. "Archaeology from below." Public Archaeology 1 (1): 21-33. doi:10.1179/ pua.2000.1.1.21.

Fawcett, C., J. Habu, and J. M. Matsunaga. 2008. "Introduction: Evaluating Multiple Narratives: Beyond Nationalist, Colonialist, Imperialist Archaeologies." In Evaluating Multiple Narratives: Beyond Nationalist, Colonialist, Imperialist Archaeologies, edited by J. Habu, C. Fawcett, and J. M. Matsunaga, $1-11$. New York: Springer.

Fritz, J. M., and F. T. Plog. 1970. "The Nature of Archaeological Explanation.” American Antiquity 35 (4): 405-12. doi:10.2307/278113.

Funari, P. P., and M. Bezerra. 2012. "Public Archaeology in Latin America." In The Oxford Handbook of Public Archaeology, edited by R. Skeats, et al., 100-15. Oxford: Oxford University Press.

Garazhian, O. 2014. "Encounters and Questions: An Archaeologist from a Trans-Modern Society." Archaeologies 10 (1): 3-26. doi:10.1007/s11759-012-9218-8.

Giaccardi, E., ed. 2012. Heritage and Social Media. Understanding Heritage in a Participatory Culture. Oxford: Routledge.

Gnecco, C., and A. Dias, eds. Forthcoming. "Disentangling Contract Archaeology." International Journal of Historical Archaeology. 
Grima, R. 2004. "Archaeological Research and the Public." In Paper delivered to the Sixth European Commission Conference on Sustaining Europe's Cultural Heritage: From Research to Policy. Accessed October 16, 2013. http://www.ucl.ac.uk/sustainableheritage/conferenceproceedings/pdf/3b.2_grima.pdf

Grima, R. 2010. "A Reply to "What Is Public Archaeology?" Present Pasts 1 (1): 53-54. Accessed October 16, 2013. doi:10.5334/pp.10.

Hawkes, J. 1968. “The Proper Study of Mankind.” Antiquity 42: 255-62.

Henson, D. 2010. "The Academy and the Public." In Unquiet Pasts: Risk Society, Lived Cultural Heritage, Re-Designing Reflexivity, edited by I. Russell and S. Koerner, 209-22. Farnham: Ashgate.

Hodder, I. 1992. Theory and Practice in Archaeology. London: Routledge.

Hodder, I. 1999. The Archaeological Process: An Introduction. Oxford: Blackwell.

Hodder., I., ed. 2000. Towards Reflexive Method in Archaeology: The Example of Catalhöyük. Cambridge: McDonald Institute of Research and British Institute of Archaeology at Ankara.

Hodder, I. 2002. "Archaeological Theory." In Archaeology: The Widening Debate, edited by B. Cunliffe, W. Davies, and C. Renfrew, 77-90. Oxford: British Academy.

Hodder, I. 2004. Archaeology beyond Dialogue. Salt Lake City: University of Utah Press.

Hodder, I. 2008. "Multivocality and Social Archaeology." In Evaluating Multiple Narratives: Beyond Nationalist, Colonialist, Imperialist Archaeologies, edited by J. Habu, C. Fawcett, and M. Matsunaga, 196-212. New York: Springer.

Holliman, R., J. Thomas, S. Smidt, E. Scanlon, and L. Whitelegg, eds. 2009. Practising Science Communication in the Information Age: Theorising Professional Practices. Oxford: Oxford University Press.

Holliman, R., E. Whitelegg, E. Scanlon, S. Smidt, and J. Thomas, eds. 2009. Investigating Science Communication in the Information Age: Implications for Public Engagement and Popular Media. Oxford: Oxford University Press.

Holtorf, C. 2005a. From Stonehenge to Las Vegas. Archaeology as Popular Culture. Walnut Creek: Altamira Press.

Holtorf, C. 2005b. "Beyond Crusades: How (Not) to Engage with Alternative Archaeologies." World Archaeology 37 (4): 544-51. doi:10.1080/00438240500395813.

Holtorf, C. 2006. "Experiencing Archaeology in the Dream Society." In Images, Representations and Heritage, edited by I. Russell, 161-75. New York: Springer.

Holtorf, C. 2007. Archaeology is a Brand! The Meaning of Archaeology in Contemporary Popular Culture. Oxford: Archaeopress.

Holtorf, C., and A. Högberg. 2005. "Talking People: From Community to Popular Archaeologies.” Lund Archaeological Review 11/12: 79-88.

Hudson, K. 1981. A Social History of Archaeology: The British Experience. London: Macmillan.

Hughes, J. 2011. "Community Archaeology: A Catch-All Strategy?" In Community Archaeology. Themes, Methods and Practices, edited by G. Moshenska and S. Dhanjal, 58-62. Oxford: Oxbow Books.

IfA. 2013. By-laws. Code of Conduct (Last update: 20-Mar-14). Reading, MA: Institute for Archaeologists. Irwin, A., and B. Wynne, eds. 1996. Misunderstanding Science? The Public Reconstruction of Science and Technology. Cambridge: Cambridge University Press.

Isherwood, R. 2009. "Community Archaeology. A Study of the Conceptual, Political and Practical Issues Surrounding Community Archaeology in the United Kingdom Today." Unpublished PhD Thesis: University Of Manchester.

Jameson, J. H., ed. 1997. Presenting Archaeology to the Public. Digging for Truths. Walnut Creek, CA: Altamira Press. 
Jensen, B. 2010. “'Let's Not Go to the Dogs Tonight': Rhetoric as a Strategy of Accountability in Archaeological Outreach." In Unquiet Pasts: Risk Society, Lived Cultural Heritage, Re-Designing Reflexivity, edited by I. Russell and S. Koerner, 173-84. Farnham: Ashgate.

Johnson, M. 1999. Archaeological Theory: An Introduction. Oxford: Blackwell.

Jones, B. 1984. Past Imperfect: The Story of Rescue Archaeology. London: Heinemann.

Kamm, F. M. 2007. Intricate Ethics: Rights, Responsibilities and Permissible Harms. Oxford: Oxford University Press.

Kenny, J. 2009. "Unpicking Archaeology and Heritage." In Taking Archaeology Out of Heritage, edited by E. Waterton and L. Smith, 209-29. Newcastle upon Tyne: Cambridge Scholars.

Lizama Aranda, L. L., and B. A. Camargo. 2014. "Access to Archaeological Heritage in Mexico: Its Impact on Public Participation in Archaeology." In Public Participation in Archaeology, edited by S. Thomas and J. Lea, 139-45. Woodbridge, VA: Boydell Press.

Macdonald, S. 2002. Behind the Scenes at the Science Museum. Oxford: Berg.

Mapunda, B. 2013. "Get off My Land! Towards a Mutual Understanding in Archaeological Field Conflicts." AP: Online Journal in Public Archaeology 3: 74-96.

Marshall, Y. 2002. "What Is Community Archaeology?” World Archaeology 34 (2): 211-19. doi:10.1080/ 0043824022000007062.

Matsuda, A., and K. Okamura. 2011. "Introduction: New Perspectives in Global Public Archaeology." In New Perspectives in Global Public Archaeology, edited by A. Matsuda and K. Okamura, 1-18. London: Springer.

McDavid, C. 2004. "Towards a More Democratic Archaeology? the Internet and Public Archaeological Practice." In Public Archaeology, edited by N. Merriman, 159-87. London: Routledge.

McDavid, C., and F. McGhee. 2010. "Commentary: Cultural Resource Management, Public Archaeology, and Advocacy." In Handbook of Postcolonial Archaeology, edited by J. Lydon and U. Z. Rizvi, 481-94. Walnut Creek, CA: Left Coast Press.

McGill, A. E. 2014. "Situating Public Archaeology in Crooked Tree, Belize.” In Public Participation in Archaeology, edited by S. Thomas and J. Lea, 129-38. Woodbridge, VA: Boydell Press.

McGimsey, C. R. 1972. Public Archeology. New York: Seminar Press.

McGuire, R. 2008. Archaeology as Political Action. Berkeley: University of California Press.

McManamon, F. P. 2000. "The Protection of Archaeological Resources in the United States: Reconciling Preservation with Contemporary Society." In Cultural Resource Management in Contemporary Society: Perspectives on Managing and Preserving the Past, edited by A. Hatton and F. P. McManamon, 40-54. London: Routledge.

Merriman, N. 2000. "The Crisis of Representation in Archaeological Museums." In Cultural Resource Management in Contemporary Society, edited by A. Hatton and A. P. McManamon, 300-9. London: Routledge.

Merriman, N. 2002. "Archaeology, Heritage and Interpretation.” In Archaeology: The Widening Debate, edited by B. Cunliffe, W. Davies, and C. Renfrew, 541-66. Oxford: Oxford University Press.

Merriman, N. 2004. "Introduction: Diversity and Dissonance in Public Archaeology." In Public Archaeology, edited by N. Merriman, 1-17. London: Routledge.

Merriman, N., and H. Swain. 1999. “Archaeological Archives: Serving the Public Interest?” European Journal of Archaeology 2 (2): 249-67. doi:10.1179/eja.1999.2.2.249.

Moore, M. 2004. Objectivity in Ethics and Law. Aldershot: Ashgate.

Moreno Torres, S., and N. Marquez-Grant. 2011. "Fourty Years of “Archaeology for Children'.” AP: Online Journal in Public Archaeology 1: 29-44. 
Moser, S., D. Glazier, J. E. Phillips, L. N. El Nemr, M. S. Mousa, R. N. Aiesh, S. Richardson, A. Conner, and M. Seymour. 2002. "Transforming Archaeology through Practice: Strategies for Collaborative Archaeology and the Community Archaeology Project at Quseir, Egypt." World Archaeology 34 (2): 220-48. doi:10.1080/0043824022000007071.

Moshenska, G. 2010. “What Is Public Archaeology?” Present Pasts 1 (1): 46-48. doi:10.5334/pp.7. Moshenska, G., and T. Schadla-Hall. 2011. "Mortimer Wheeler's Theatre of the Past." Public Archaeology

10 (1): 46-55. doi:10.1179/175355311X12991501673221.

Naffé, B. O. M., R. Lanfranchi, and N. Schlanger, eds. 2008. L'archeologie Preventive en Afrique. Enjeux et Perspectives. Saint-Maur-des-Fossés: Éditions Sépia.

Okamura, K. 2011. "From Object-Centred to People-Focused: Exploring a Gap between Archaeologists and the Public in Contemporary Japan." In New Perspectives in Global Public Archaeology, edited by A. Matsuda and K. Okamura, 77-86. London: Springer.

Piccini, A. A. 2006. Television Heritages: Heritage Counts. York: Council for British Archaeology, English Heritage.

Piccini, A. A. 2010. "The Stuff of Dreams: Archaeology, Audience and Becoming Material." In Unquiet Pasts: Risk Society, Lived Cultural Heritage, Re-Designing Reflexivity, edited by I. Russell and S. Koerner, 305-26. Farnham: Ashgate Publishing Ltd.

Querol, M. A. 2011. "El patrimonio cultural en las universidades españolas: no solo una cuestión de tiempo." Patrimonio Cultural de España 5: 75-89.

Rassool, C. 2010. "Power, Knowledge and the Politics of Public Pasts." African Studies 69 (1): 79-101. doi:10.1080/00020181003647215.

Reid, P. 2008. "Community Archaeology: From the Grassroots." Current Archaeology 216: 21. Accessed February 1, 2012. http://www.archaeology.co.uk/blog/opinion/community-archaeology-from-the-grassroots.htm

Robinson, R., and D. Picard 2006. Tourism, Culture and Sustainable Development. Paris: UNESCO. Accessed January 19, 2014. http://unesdoc.unesco.org/images/0014/001475/147578e.pdf

Sand, C., J. Bolé, and A. Ouetcho. 2011. "Archaeology in a Multicultural and a Multi-Ethnic Nation under Construction: The Case of New Caledonia (Southern Melanesia)." In New Perspectives in Global Public Archaeology, edited by A. Matsuda and K. Okamura, 113-26. London: Springer.

Saucedo Segami, D. D. 2011. "Looking for an Identity: Archaeologists, Local Communities and Public Archaeology in Peru." In New Perspectives in Global Public Archaeology, edited by A. Matsuda and K. Okamura, 251-62. London: Springer.

Scanlon, T. M. 2003. The Difficulty of Tolerance: Essays in Political Philosophy. Cambridge: Cambridge University Press.

Schadla-Hall, T. 1999. "Editorial: Public Archaeology." European Journal of Archaeology 2 (2): 147-58. doi:10.1179/eja.1999.2.2.147.

Schadla-Hall, T. 2004. “The Comforts of Unreason.” In Public Archaeology, edited by N. Merriman, 255-71. London: Routledge.

Schadla-Hall, T., G. Moshenska, and A. Thornton. 2010. "Editorial.” Public Archaeology 9 (2): 62-63. doi:10.1179/175355310X12780600917513.

Schlanger, N., and K. Aitchison, eds. 2010. Archaeology and the Global Economic Crisis. Multiple Impacts, Possible Solutions. Tervuren: Culture Lab Editiòns.

Shanks, M., and C. Tilley. 1987. Re-Constructing Archaeology. London: Routledge.

Shepherd, N. 2011. "Archaeology Dreaming: Postapartheid Urban Imaginaries and the Remains of the Prestwich Street Dead." In New Perspectives in Global Public Archaeology, edited by A. Matsuda and K. Okamura, 156-66. London: Springer. 
Shoocongdej, R. 2011. "Public Archaeology in Thailand." In New Perspectives in Global Public Archaeology, edited by A. Matsuda and K. Okamura, 95-112. London: Springer.

Skeates, R., C. McDavid, and J. Carman, eds. 2012. The Oxford Handbook of Public Archaeology. Oxford: Oxford University Press.

Smith, G. S. 2006. "The Role of Archaeology in Presenting the Past to the Public." In Images, Representations and Heritage, edited by I. Russell, 122-37. New York: Springer.

Tantaleán, H., and M. Aguilar. 2012. La Arqueología Social Latinoamericana. De la Teoría a la Praxis. Bogotá: Ediciones Uniandes.

The Public Archaeology Group. 2013. "Blog.” Accessed November 15, 2014. http://centralpag.blogspot.com

Thiaw, I. 2011. "Digging on Contested Grounds: Archaeology and the Commemoration of Slavery on Gorée Island, Senegal." In New Perspectives in Global Public Archaeology, edited by A. Matsuda and K. Okamura, 127-38. London: Springer.

Thomas, S. 2010. "Community Archaeology in the UK: Recent Findings." York: Council for British Archaeology. Accessed October 3, 2013. http://www.britarch.ac.uk/research/community

Tully, G. 2007. "Community Archaeology: General Methods and Standards of Practice." Public Archaeology 6 (3): 155-87. doi:10.1179/175355307X243645.

Ucko, P. J. 1990. "Foreword." In The Politics of the Past, edited by P. Gathercole and D. Lowenthal, ixxxi. London: Unwin Hyman.

Ucko, P. J., ed. 1995. Theory in Archaeology: A World Perspective. London: Routledge.

Ucko, P. J. 1997. Academic Freedom and Apartheid. London: Duckworth.

Wang, T. 2011. "Public Archaeology' in China: A Preliminary Investigation." In New Perspectives in Global Public Archaeology, edited by A. Matsuda and K. Okamura, 43-56. London: Springer.

Waterton, E. 2005. "Whose Sense of Place? Reconciling Archaeological Perspectives with Community Values: Cultural Landscapes in England.” International Journal of Heritage Studies 11 (4): 309-25. doi:10.1080/13527250500235591.

Waterton, E. 2010. Politics, Policy and the Discourses of Heritage in Britain. Basingstoke: Palgrave Macmillan.

Waterton, E., and L. Smith. 2010. "The Recognition and Misrecognition of Community Heritage." International Journal of Heritage Studies 16 (1-2): 4-15. doi:10.1080/13527250903441671.

Wheeler, R. E. M. 1956. Archaeology from the Earth. Harmondsworth: Penguin.

WAC (World Archaeological Congress). 2013. "About WAC.” Accessed December 25. http://www. worldarchaeologicalcongress.org/about-wac

Dr Lorna-Jane Richardson is a research associate of the UCL Centre for Digital Humanities and her research focuses on the use of social media in archaeology. She recently obtained her $\mathrm{PhD}$ at UCL in public archaeology and has extensive experience in the field.

Jaime Almansa-Sánchez is founder and manager of JAS Arqueología S.L.U., a commercial firm devoted to public archaeology. His research focuses on archaeological management and public archaeology. He is editor of AP: Online Journal in Public Archaeology. 